\title{
Teachers' views on values education: $A$ qualitative study in Sweden and Turkey
}

Robert Thornberg and Ebru Oğuz

\section{Linköping University Post Print}

\section{Tweet}

N.B.: When citing this work, cite the original article.

Original Publication:

Robert Thornberg and Ebru Oğuz, Teachers' views on values education: A qualitative study in Sweden and Turkey, 2013, International Journal of Educational Research, (59), 1, 49-56.

http://dx.doi.org/10.1016/j.ijer.2013.03.005

Copyright: Elsevier

http://www.elsevier.com/

Postprint available at: Linköping University Electronic Press

http://urn.kb.se/resolve?urn=urn:nbn:se:liu:diva-91056 


\title{
Teachers' views on values education: A qualitative study in Sweden and Turkey
}

\author{
Robert Thornberg ${ }^{a}$ \& Ebru Ŏguz ${ }^{b}$ \\ ${ }^{a}$ Linköping University, Linköping, Sweden \\ ${ }^{b}$ Mimar Sinan Fine Arts University, Istanbul, Turkey
}

\begin{abstract}
The aim of the current study was to examine Swedish and Turkish teachers' perspectives on values education. Qualitative interviews with 52 teachers was conducted and analyzed. Values education was mostly about compliance with societal values and norms. The learning goals or values in values education were mainly on how to treat others and on selfresponsibility. Teachers did not take a critical approach. A main method of values education reported by the teachers was to be a good role model in everyday interactions with students. Values education was largely described as an everyday practice embedded in the stream of social interactions. Furthermore, an everyday language was used when the teachers described values and values education. There was a lack of professional knowledge in this domain.
\end{abstract}

Keywords

Values education, Moral education, Ethics, Values, Teacher professionalism

\section{Introduction}

Teaching is a moral activity in which teachers have to consider the ethical complexity of teaching and the moral impact they have on their students (Carr, 2011; Colnerud, 2006; Lovat, Dally \& Toomey, 2011; Sanger \& Osguthorpe, 2005; Shapira-Lishchinsky, 2009, 2011). All kinds of activities in schools in which students learn or develop values and morality are often referred to as values education (e.g., Halstead, 1996; Lovat, 2011; Powney, Cullen, Schlapp, Johnstone \& Munn, 1995; Taylor, 1994), and a distinction can be made between explicit and implicit values education. Whereas explicit values education refers to schools' official curriculum of what and how to teach values and morality, including teachers' explicit intentions and practices of values education, implicit values education is associated with a hidden curriculum and implicit values, embedded in school and classroom practices (Halstead, 1996; Thornberg, 2008a). Even though the concepts of values education and moral education sometimes are used interchangeably, we use values education in line with Taylor $(1994,2006)$ as an overarching concept including concepts such as moral education, character education, and citizenship education. Based on a comparative overview of a survey of 26 European countries, Taylor (1994) concluded that the scope of values education is often complex and includes a number of themes, many of which overlap, closely related to the historical and ideological evolution of each country. Examples of identified themes are moral, religious, civic, democratic, national, pastoral, personal, and social goals and issues.

\section{Different approaches to values education}

Two general approaches to values education are usually described and contrasted in the literature (e.g., Halstead, 1996; Solomon, Watson \& Battistich, 2001). The traditional approach emphasizes adult transmission of the morals of society through character education, direct teaching, exhortation, and the use of rewards and punishments (Durkheim, 1961). The aim is to teach and discipline students to develop good character and virtues, and to conform to the dominant values, legitimate rules, and the authority of society. Examples of virtues to inculcate in character education are "being honest, hardworking, obeying legitimate authority, 
kind, patriotic and responsible" (Jones, 2009, p. 39). In contrast, the progressive or constructivist approach "emphasizes children's active construction of moral meaning and development of a personal commitment to principles of fairness and concern for the welfare of others through processes of social interaction and moral discourse" (Solomon et al., 2001, p. 573). Reasoning and explanations, deliberative discussion about moral dilemmas, and participation in decision-making processes are viewed as typical methods for this approach (Dewey, 1916; Nucci, 2006; Power, Higgins \& Kohlberg, 1989). The aim is to promote moral autonomy, rational thinking, moral reasoning skills, and democratic values and competence among the students. Nevertheless, this distinction has been criticized for simplifying the field (e.g., Sanger \& Osguthorpe, 2005), and educational programs or approaches can, for example, fall between a traditional and a constructivist approach (Berkowitz, 2011; Narvaez, 2006). Moreover, a third approach or position in the field of values education is discernible - a critical approach, which claims that moral influence in school, especially in the practice of school discipline and in hidden curriculum, can be questioned and has far-reaching effects without being noticed (Bernstein, 2000; Giroux \& Penna, 1983; Jones, 2009;). Jones (2009) actually makes a distinction between critical and postmodern orientations to values education, in which the former is about engaging students more actively in social justice issues and political activism, whereas the later "favours the teaching of multiple perspectives on issues and knowledge, and a critical deconstructive orientation towards social values and practicessuch as the hegemony or discursive truths/assumptions of any given time or culture are revealed" (p. 42). In this article, we categorize both latter orientations as a critical approach to values education.

\section{Values education in Sweden}

Values education has always been a part of the school curriculum in Sweden. During the 19th century, the aim of values education was to inculcate Christian beliefs and moral values, duties, and character from a patriarchal perspective. At the end of the 19th century and the outset of the 20th century, however, the influence of the Church on the Swedish school system gradually decreased. Especially after the Second World War, progressive ideals of democracy and democratic citizenship education in parallel with scientific ideals of rationality and objectivity challenged the traditional and conservative approach of values education in Swedish schools. The ultimate aim became the realization of the political ideas of democracy, equality, and social justice (Orlenius, 2001; Svingby, 1994). According to their present official curriculum policy document (Skolverket, 2011), primary schools in Sweden today have the task of forming, mediating, and firmly establishing democratic values and norms in their students. The mission is to let all students develop skills to make and verbalize ethical decisions, to respect the human dignity of others, to help others, and to oppose and counteract oppression and harassment of individuals or groups. Schools in Sweden do not teach values education as a specific subject, however. Instead, values education is more or less integrated with other teaching subjects, especially social studies and religion, but even in subjects such as history, biology, and physical education. Moreover, values education is also expected to be expressed in the informal curriculum, for example in classroom management, teacher-student interactions, rule setting, student participation, conflict management, and counteracting harassment and discrimination.

\section{Values education in Turkey}

The general targets of the Turkish National Education were identified through the Basic Law of National Education No 1739 (MoNE, 1973). This law determines both the aims and fundamental principles of the national education. The fundamental principles are universality and equality, needs of the individual and society, orientation, educational right, equality of oppor- 
tunity and possibility, continuity, the revolution and principles of Atatürk, democracy education, secularity, scientific education, planning, mixed education, cooperation of school and parents, and education in all places (MoNE, 1973). There has been a growing awareness of values education in Turkey in recent years. In many schools, energetic work has begun preparing new projects in regard to values education. This issue has become a focus of interest for many (Şişman, 2012). Values and values education are emphasized especially in life sciences and social studies curricula; in other courses it has taken place within the hidden curriculum in Turkey's primary schools (Demirel, 2009).

\section{Research aims}

The aim of the current study was to examine Swedish and Turkish teachers' perspectives on values education. Sweden and Turkey are both European countries with a secular school system. However, Sweden is located in the northern part of Europe and has a Christian cultural history, Turkey is located in the southeast of Europe and with a Muslim cultural background. Consequently, we found it of interest to conduct the study in both countries.

In accordance with the aim, the following research questions were explored: What values do teachers consider important to teach or focus upon in their practice of values education? How do teachers describe their practice of values education? What do teachers refer to as the basis for their choices of values and methods in their practice of values education?

\section{The researchers' perspectives}

Here we take a broad interactionist and social constructionist position (Atkinson \& Housley, 2003; Berger \& Luckmann, 1967). Identity, social life and morality are inescapably social, collective and cultural processes, constructed and reconstructed in everyday social interactions and individuals' interpretation processes. According to this perspective, morality refers to "a broader sociological concern with the achievement of a socially organized identity and the construction of actors as moral agents, responsible for their actions and subject to the evaluations of others" (Atkinson \& Housley, 2003, p. 63). Interpretations and meanings are constructed and mediated in and by social interactions. People act in a world they define. Even if there may be a reality out there, people's definition of the situation is far more important for what they do (Charon, 2007). This interactionist and social constructionist position makes us sympathize with a critical approach to values education. Nevertheless, instead of using the "sacred" text of a particular tradition as a starting-point, we have been suspicious of grand theory, with reference to Atkinson and Housley (2003), and have been quite free from the constraints of orthodoxy. Because of the complexity of and different present perspectives on morality and values education, we have stressed the need of knowing and considering the vast range of normative ethics, moral developmental theories and approaches to values education in order to address the complexity, differences and ambiguity. Thayer-Bacon (2001) uses as a metaphor the well-known poem of six blind men who explore an elephant from different positions and describe it as a rope, a tree, a fan, a snake, a wall, and a spear on the basis of the part of the elephant that each man touched. With reference to her epistemological standpoint, we (a) insist on the need for pluralism (i.e., a conversation between different perspectives, in relation to the elephant, to reach a more qualified understanding), (b) accept fallibilism, which holds that we can never attain knowledge that is certain because we are fallible, limited, and contextual beings, and (c) claim that knowledge is a social process of knowing that is continually in need of (re)adjustment, correction, and (re)construction. This pragmatic and pluralist perspective has colored our data collection and analysis procedures.

\section{Method}




\subsection{Participants}

The participants of the study comprise 52 primary school teachers ( 27 women and 25 men). The Swedish sample consisted of 26 teachers (14 women and 12 men), ranging from 28 to 62 years old, located in three cities. Their professional experience as teachers ranged from 2 to 36 years. Sixteen of them were classroom teachers at lower and middle primary school (grades 1-6), and 10 of them were subject teachers at upper primary school (grades 7-9). The subject teachers taught mathematics, physics, biology, chemistry, social studies, history, religion, Swedish, English, and French. The Turkish sample comprised 26 teachers (13 women and 13 men), ranging from 22 to 50 years old, located in two cities. Their professional experience as teachers ranged from 1 to 26 years. Fourteen of them were classroom teachers at lower and middle primary school (grades 1-5), and 11 of them were subject teachers at upper primary school (grades 6-8). Subjects represented by the subject teachers were mathematics, science, technology, social studies, religion, Turkish, English, and guidance.

\subsection{Data collection and analysis}

Individual qualitative semi-structured interviews were conducted in order to examine the practicing teachers' views on values education. We used the qualitative interview method because it encourages participants to speak for themselves and in their own way. The teachers were asked to describe their practices of values education and to verbalize the values they thought were important for students to develop or learn from school. The teachers were also asked about what influenced their way of thinking about and working with values education and their choice of values in values education. The interviews ranged in duration from 20 to 90 minutes. Each interview was audio-recorded and transcribed verbatim. Qualitative analysis of data was conducted by a flexible and pragmatic use of methods from the grounded theory tradition (e.g., Charmaz, 2006; Glaser \& Strauss, 1967). Data have been coding line-by-line and themes and concepts have been emerged by constantly comparing data with data, data with code, code with code, and so on. We have systematically analyzed similarities and differences, and we were surprised to find so much cross-cultural similarities.

\section{Results}

\subsection{Values in values education}

In both the Swedish and the Turkish interview data, when teachers reported values they viewed as important for their students learn, they mostly described what could be called relational values, that is, values about how to treat others, such as showing other people respect, being kind and nice to others, showing empathy, treating others in the same way as you want to be treated, caring, being tolerant, helping others, treating others fairly or justly, and not harassing or harming others. (e.g., "They should learn the values of love, tolerance, respect and collaboration at school," Turkish female teachers, grades 1-5; "According to my point of view, there are some really basic values: Respect, compassion, and responsibility. It's kind of, yeah, a lot of other important norms are built upon them", Swedish female teacher, grades 13). Showing other people respect was the value most often referred to by both Swedish and Turkish teachers.

The second most common set of values that the teachers reported as important values to teach their students were self-responsibility values, such as taking responsibility for yourself and your actions, honesty, doing your best in every situation, self-awareness, self-discipline, self-control, and following rules (e.g., "Encourage them to gain self-awareness," Turkish male teacher, grades 1-5; "For me, it's important that the students learn to take responsibility for themselves and their actions, to reflect upon how they behave in different situations, and to do as best as they can," Swedish female teacher, grades 7-9). 
Among Turkish as well as Swedish teachers, the major aim of values education was to socialize acceptable or appropriate behavior, to influence students to internalize societal norms and expectations (e.g., "The kids have to learn the acceptable behavior in social settings, sharing equally, learn to be respectful to the others," Turkish female teacher, grades 68). The ways teachers expressed relational and self-responsibility values actually reflected a functional view of values education: teaching students to accept and comply with the societal values and norms in order to maintain the order, harmony, and functions of the society.

Teacher: I really think that the most important with values education is to teach the students to behave as you should behave.

Interviewer: To behave as you should behave?

Teacher: $\quad$ Yes, we have a lot of rules in school, rules about how to treat others and rules about how to behave in the classroom and so on. I mean, these rules reflect the rules and laws of our society, and students have to learn these rules, to understand and follow the rules of our society. If people didn't care about the rules and laws, the society would collapse.

(From an interview with a Swedish male teacher, grades 7-9)

Their views of values and values education mirror Bernstein's (2000) concept of regulative discourse, which refers to a discourse in school that constructs the rules of social order in school. Bernstein claims that this is a moral discourse because it creates the criteria that give rise to character, conduct, manners, and the like. In contrast to this regulative discourse, many Swedish teachers and some Turkish teachers also focused on supporting or developing psychological strengths and confidence within the students, which could be labeled selfenhancing values. They talked about supporting students in developing a positive self-image, good self-confidence, high self-esteem, or self-efficacy in different areas as important values in values education (e.g., "Strengthening of their self-confidence, and you should have a good self-confidence," Swedish female teacher, grades 1-3; "Gaining self-confidence", Turkish male teacher, grades 6-8).

In addition, democratic-participation values were also expressed as important values in values education but in a lesser extent than relational, self-responsibility, and self-enhancing values. These values included freedom of speech, creating democratic schools/classrooms, participating in decision-making processes, and conducting democratic conversations and meetings (e.g., "It's important to develop their democratic attitudes and skills by letting them have a say and participate in class councils," Swedish male teacher, grades 4-6). Finally, a few Turkish teachers but no Swedish teacher talked about nationalism as an important value in values education, in terms of loving the motherland, fostering national unity, and encouraging patriotism (e.g., "love your family, motherland and nation," Turkish male teacher, grades 6-8).

\subsection{Accomplishing values education}

According to most Swedish and Turkish teachers, a main method of values education was to be a good role model as a teacher in everyday interactions with students (e.g., "To be a decent role model. The students adopt their teacher's behaviors as theirs," Turkish female teacher, grades 1-5; "First, to be a role model and don't say offensive things or do offensive things, to really show that I think all are equal, listening to all," Swedish female teacher, grades 1-3). In line with this, many Swedish and Turkish teachers stated that their work of values education was largely an everyday practice embedded in the stream of social interactions. It was an informal curriculum that took place all the time (e.g., "Day-to-day, and, well, I think that it permeates everything I do," Swedish female teacher, grades 1-3). Furthermore, some of the Swedish teachers actually admitted that their values education was mostly or partly unreflec- 
tive or unconscious (e.g., "I do so many things unconsciously," Swedish female teacher, grades 1-3; "It's nothing I reflect upon. I just do it," Swedish female teacher, grades 4-6).

Furthermore, Swedish teachers reported that their practice of values education was, to a great extent, about intervening when things happen, that is, reacting to student behavior, including rule transgressions, peer harassment, disruptive behavior, and peer conflicts (e.g., "The significant work with values education is not a part of the planned instructions in the classroom but rather how you deal with things that constantly pop up every day and then you talk about how to behave and what you could have done instead and so on. That's how you learn things," Swedish female teacher, grades 4-6). Once again, values education appeared to be fused with classroom management and school discipline, that is, maintaining school and classroom rules in order to get students to behave appropriately and in accordance with relational values and self-disciplinary values. Some of the teachers associated this situated reactive practice with the importance of being a good leader and role model, in order to be effective.

Interviewer: Would you like to tell a bit about how you work with values education?

Teacher: Well, I think that's basic. You have that in everything. Number one is to be a clear leader, act as a good role model and react and lead the students. So in many respects, it's about being a distinct role model, to react and be very powerful, which I think I am. If I react toward something I don't think is OK, I do that very clearly, and even if it's something positive, I'm clear with that too and try to encourage that instead.

Interviewer: Uh-huh.

Teacher: $\quad$ So you have to deal with situations when they pop up and talk about these events with the involved children.

(From an interview with a Swedish female teacher, grades 1-3)

This reactive approach was rarely mentioned by the Turkish teachers, who more often focused on (explicit and implicit) proactive methods and strategies. Swedish and Turkish teachers gave examples of proactive implicit values education such as working with rules at the beginning of the fall semester when the class of students was new or using their leadership role in order to influence the social climate in a positive way (e.g., "Creating a democratic class atmosphere is important. ... I allow them [students] to evaluate themselves and their friends freely. I provide an atmosphere where they develop their ideas, investigate, and improve skills to ask questions," Turkish male teacher, grades 6-8). Viewing values education as an everyday informal and ongoing process predominated in both the Swedish and Turkish samples.

Nevertheless, many Turkish teachers and some Swedish teachers also reported particular methods as ways of enacting values education, like showing films or reading a book aloud with follow-up discussions, role playing, or classroom discussion based on the content of TV news or the mass media (e.g., "We view videos, short films with relevance for values education. I found that drama is the most valuable method, because it facilitates students to feel empathy and differentiate right from wrong," Turkish female teacher, grades 1-5). There were also teachers who mentioned school democratic meetings, such as class councils, as a way of working with values education (e.g., "Once a week we have a class council in which the students can discuss things and vote. This helps them to develop skills in making arguments, listening to others, and participating in democratic discussions," Swedish male teacher, grades 4-6). School democracy and class councils as means of accomplishing values education were nevertheless quite uncommon in the interview data.

In addition, some of the Turkish and Swedish teachers associated values education with the content in particular school subjects (social studies, religion, history, life sciences, and biology; e.g., "Discussing ethics from different religious perspectives and teaching students to 
think ethically is a part of what we do in religious education," Swedish female teacher, grades 7-9). However, teachers more commonly differentiated teaching school subjects as their ordinary practice and values education as something they have to do in addition to their ordinary practice.

\subsection{Personal references and everyday language}

Consistently, both Swedish and Turkish teachers used an everyday language when they described values and values education. Some of the teachers actually found it hard to verbalize their practice during the interviews (e.g., "I find it hard to describe this work. I usually go for what I feel will be good. . . . I go more on my gut feelings, what I think, and then I talk about it, and, well, I really can't do more than that, I think," Swedish female teacher, grades 4-6). When they were asked about how they have received or appropriated the values they saw as important to teach the students, Swedish as well as Turkish teachers referred to their own childhood and their parents, to their personal experiences as children, to adults and teachers in their lives, and to sources such as personal worldviews, emotions, personal conceptions, and common sense (e.g., "Throughout my life, I have come to these days by learning these values. What I could teach to my students is what I have learned from my family and my environment," Turkish female teacher, grades 1-5).

Common sense was a popular value reference among the Swedish teachers. When they were asked to explain what they meant by common sense, they referred to making wise decisions guided by social norms and rationales (e.g., "Common sense is about understanding and following common rules in our society like respect others, don't harm others, and treat others in the same way as you want to be treated," Swedish female teacher, grades 6-9), or to their own conscience ("inner compass"), as in the excerpt below.

Interviewer: What is common sense? What does it mean for you?

Teacher: $\quad$ You get the feeling, or as we sometimes put it, the inner compass that makes you feel what's right or wrong. "It has to stop now, I mustn't go any further because then it will become wrong. I shall not say this because he or she will be upset."

(From an interview with a Swedish female teacher, grades 1-3)

Some teachers referred to cultural tradition and religion (e.g., "I've got them [the values] from our culture, I think, and our old religious tradition. Treat others as you would like to be treated yourself is the old stuff that you can find in every religion," Swedish female teacher, grades 4-6). In addition, a few teachers also talked about mass media as a source (e.g., "No one in the whole world is worth more than you. Neither is anyone worth less then you. It's something Stellan Skarsgård [a Swedish actor] has said on TV that his father told him, and I thought that was good," Swedish female teacher, grades 4-6). However, in no single case, did we find references to a qualified professional body of knowledge - such as moral philosophy or normative ethics, educational philosophy, values educational theories, moral psychology, sociology, or political science - as a base for the teachers' choices, discussions, or legitimization of values. Moreover, when teachers were asked about the basis for their approaches and methods of values education, no one referred to theories or research within fields like values education (including moral education and citizenship education), educational psychology, critical pedagogy, social or moral development, didactics, social psychology, political science, or sociology of education. Once again, they referred to personal conceptions and experiences like common sense, an inner moral compass, their own personality (e.g., "It's all about who I am as a person. . . . Every teacher has his or her own unwritten rulebook," Swedish female teacher, grades 1-3), learning from other colleagues, their own experiences as parents, and so on. 
According to some teachers, their own teacher education program did not really prepare them for values education, which in turn might explain their use of personal language and lack of professional knowledge in this domain.

Interviewer: How do you view your work with values education?

Teacher: Well, that's what I'm not trained for, so I have to use my common sense and my experiences from my own kids.

Interviewer: So you have to lean on that instead?

Teacher: $\quad$ Yes, because I'm trained to be a teacher, not a mom.

(From an interview with a Swedish female teacher, grades 1-3.)

In the excerpt above, the teacher actually associated her practice of values education with being "a mom." As a result of the personal references and preferences, many teachers actually represented values education in terms of disciplining, parenting, or bringing up the students as well as maintaining social order in the school and classroom.

\section{Discussion}

A huge part of the Swedish and Turkish teachers' narratives can be associated with the traditional approach of values education with a strong focus on transmitting taken-for-granted dominant values, particular in terms of rules and character, to the students in order to create rule-conforming, honest, respectful, self-disciplined, kind, and nice people (cf. Durkheim, 1961; Solomon et al., 2001). Furthermore, the teachers depicted role modeling as a primary means by which values education occurred, which can be compared with a recent U.S. study (Sanger \& Osguthorpe, 2013) showing that modeling was the most common explanation preservice teachers offered of how moral education works. Role modeling as an explicit teaching strategy brought Bandura's (1977) social learning theory to the fore (even though none of the teachers in the current study cited Bandura or mentioned his theory) and could be interpreted as in accordance with a traditional approach of values education and its underlying transmission model.

At the same time, some of the Swedish and Turkish teachers also discussed democratic participation as an important value in values education as well as creating a good moral and democratic climate and having classroom discussions and democratic meetings or student participation, which all can be associated with a progressive/constructivist approach (cf., Dewey, 1916; Nucci, 2006; Power et al., 1989; Solomon et al., 2001). In addition, the presence of self-enhancing values (e.g., helping students to develop a positive self-image, good self-confidence, or high self-esteem) in the reports from many Swedish teachers and some Turkish teachers might also be linked to a child-centered, progressive approach.

Sanger and Osguthorpe (2005) argue that the distinction between traditional and progressive/constructivist approach is problematic because it simplifies the field. In line with their critics and Thornberg's (2008b) previous findings, the narratives elicited from many teachers in the current study reflected hybrids of traditional and progressive/constructivist approaches to values education, but with the former predominant - that is, traditionalism with more or fewer elements of progressivism. Teachers' propensity to hybrid positions between traditionalism and progressivism/constructivism has also been indicated in prior Turkish studies (e.g., LePage et al., 2011; Oğuz, 2012; Yıldırım, 2009). For example, in Yıldırım (2009), teachers reported that they taught values to children by modeling, using true stories including different values, using situations to explain right from wrong, and continuously questioning classroom events together with the students.

Neither the Swedish nor the Turkish teachers' report could be associated with a critical approach to values education (cf., Bernstein, 2000; Giroux \& Penna, 1983; Jones, 2009). The 
values and the practice of values education seemed to be taken for granted by the teachers. No one of them problematized phenomena such as hidden curriculum, implicit values, norm oppression, social reproduction, power, ideologies, intersectionality, social structures, structure-agency dilemma, hegemonies, or discourses. A critical approach toward values education has been shown to be rare also in some previous studies (Jones, 2009; Thornberg, 2008b). In the present study, teachers were mostly preoccupied with behavior, rules, character, discipline, and social order, and many scholars actually have highlighted the blurred overlap between values education or moral influence, on the one hand, and classroom management and school discipline, on the other hand (e.g., Bernstein, 2000; Ling, Burman \& Cooper, 1998; Powney et al., 1995; Thornberg, 2008a).

This points to the need for adding a critical approach to values education in schools as well as the need for qualified professional knowledge and skills in values education. However, when the teachers in the current study described their references and bases for their values and values education, it became clear that the references and bases were located in the personal self rather than in the professional self. According to Colnerud and Granström (2002), an academic higher-status profession is characterized by possessing a common scientific knowledge base, self-governed professional ethics, authority (formal legitimization), and professional autonomy. They argue that teachers are not yet an academic higher-status profession in a strict sense, but rather semi-professional. Most of all, they lack a scientific common knowledge base. Instead of using a scientific based meta-language (i.e., a language that helps the professionals to reflect upon their practice and to make predictions and theoretical descriptions and explanations regarding their practice), teachers are more prone to use an everyday language as a working tool, which results in a more unconscious, intuitive, and routinized occupation role. Everyday language starts from concrete incidents and feelings as well as implicit and personal worldviews and experiences, instead of concepts and knowledge from educational theory and research, philosophy, psychology, sociology, and so on. Colnerud and Granström (2002) argue that both meta-language and everyday language are required if a professional is to do a qualified, good job.

As displayed by teachers in previous Scandinavian studies (Colnerud, 2001; Ohnstad, 2005; Thornberg, 2008a), both the Swedish and Turkish teachers in the present study displayed a lack of a meta-language in the domains of teacher ethics and values education. They never referred to theories or research in education, psychology, philosophy, sociology, political science, or other academic disciplines when they described their practice of values education. A personal rather than a professional basis for values education was also found among teachers in an Australian report on values education:

For some teachers this was taken for granted as deriving from their own upbringing or from the way in which they had raised their own children. For others, the values stance they took was the product of personal search and commitment. (Powney et al., 1995, p. 17)

When Colnerud (2001) and Thornberg (2008a) asked teachers about how they have received or appropriated the values they saw as important to focus upon in values education, they referred to their childhood, their parents, and personal experiences and worldviews. This was the very same case among the Swedish and Turkish teachers in the present study. This might, at least in part, be explained by poor training in teacher ethics and values education, which has been shown to be a problem in teacher education programs in Sweden (Bergdahl, 2006; Frånberg, 2004, 2006) as well as in other countries (e.g., Sockett \& LePage, 2002; Taylor, 1994).

Some notes of caution, nevertheless, need to be sounded regarding the present findings. The results rely on interview data, which opens up the risk of social desirability bias, memory 
distortions, and problems with ecological validity (i.e., what teachers say they do in an interview setting and what they actually do in their everyday setting would not necessarily be the same). In addition, the sample in the study limits transferability. Nevertheless, we used a cross-culture sample and actually identified significant similarities and patterns between the Swedish and Turkish teachers. Possible future research might be to more deliberatively examine the differences in values education between the two countries, with further teacher interviews or focus groups, school policy document analysis, and ethnographic research on everyday work on values education in Swedish and Turkish schools.

Considering the implication for teacher education, the lack of a qualified professional meta-language in the domain of values education identified in the current study has to be considered as an obvious obstacle to teachers' professional development and to their practice of values education (cf. Thornberg, 2008a). Hence, it is urgent that teachers become familiar with traditional, progressive/constructivist, and critical approaches to values education and with their strengths and problems or weaknesses. Therefore, teacher education has to address theories and research as well as active reflections with relevance for moral psychology and moral development, meta-ethics and normative ethics, and moral teaching and values education, including research on effective values education or "what works" (Berkowitz, 2011) and the development of professional virtues (Carr, 2011). In addition, because of the tendency among the teachers in the current study to split ordinary teaching and values education into two different tasks, there is a strong need for implementing programs in which values education and best practice pedagogy are inextricably interrelated (Lovat et al., 2011; also see Tirri, 2011). Raising teachers' ethical knowledge is particularly urgent because without a moral vocabulary, it is difficult to see how teachers can address the complexity of moral judgments they must make with either confidence or competence, how they can develop moral understanding, and how they can teach children to think about and reflect on moral issues (Sharpira-Lishchinsky, 2011; Sockett \& LePage, 2002).

\section{References}

Atkinson, P., \& Houlsey, W. (2003). Interactionism. London: Sage.

Bandura, A. (1977). Social learning theory. New Jersey: Prentice Hall.

Berger, P. L., \& Luckmann, T. (1967). The Social construction of reality. New York, NY: Anchor books.

Berkowitz, M. W. (2011). What works in values education. International Journal of Educational Research, 50, $153-158$.

Bernstein, B. (2000). Pedagogy, symbolic control and identity: Theory, research, critique (rev ed). Lanham: Rowman \& Littlefield Publishers.

Bergdahl, L. (2006). Om gemensamma värden i ett pluralistiskt samhälle: Lärarutbildares syn på och arbete med gemensamma värden i den nya lärarutbildningen [About common values in a pluralistic society: Teacher educators' view on and work with common values in the new teacher education]. Tidskrift för lärarutbildning och forskning, 13, 17-39.

Carr, D. (2011). Values, virtues and professional development in education and teaching. International Journal of Educational Research, 50, 171-176.

Charmaz, K. (2006). Constructing grounded theory. London: Sage.

Charon, J. M. (2007). Symbolic interactionism: An introduction, an interpretation an integration (9th ed.). New Jersey: Prentice-Hall.

Colnerud, G. (2001). Regler och relationer - Lärarröster om värdegrunden [Rules and relations - Teacher voices on basic values]. In Vad har värde i praktiken: Perspektiv på värdegrunden i skola, vård och omsorg. Konferensrapport: 18-19 maj 2001 (pp. 23-30). Stockholm: Lärarhögskolan i Stockholm.

Colnerud, G. (2006). Teacher ethics as a research problems: Syntheses achieved and new issues. Teachers and Teaching: Theory and Practice, 12, 365-385.

Colnerud, G., \& Granström, K. (2002). Respekt för läraryrket [Respect for teacher profession]. Stockholm: HLS Förlag.

Demirel, M. (2009). A review of elementary education curricula in turkey: Values and values education. World Applied Sciences Journal, 7, 670-678.

Dewey, J. (1916). Democracy and education. Carbondale: Southern Illinois Press.

Durkheim, E. (1961). Moral education. New York: Dover Publications. 
Frånberg, G-M. (2004). "Man måste börja med sig själv...”: Värdegrunden i den nya lärarutbildningen ["You have to start with yourselfy"': The foundation of values in the new teacher education] (Värdegrund i teori och praktik 4). Umeå: Umeå University.

Frånberg, G-M. (2006). Lärarstudenters uppfattning om värdegrunden i lärarutbildningen [Teacher students' perception of the foundation of values in the teacher education]. Tidskrift för lärarutbildning och forskning, $13,125-169$.

Giroux, H. \& Penna, A. (1983). Social education in the classroom: The dynamics of the hidden curriculum. In H. Giroux, H. \& D. Purpel (Eds), The hidden curriculum and moral education (pp. 100-121). Berkeley: McCutchan Publishing Corporation.

Glaser, B.G., \& Strauss, A.L. (1967). The discovery of grounded theory. New York: Aldine.

Halstead, J. M., (1996). Values and values education in schools. In J. M. Halstead, \& M. J. Taylor (Eds.), Values in education and education in values (pp. 3-14). London: The Falmer Press.

Jones, T. M. (2009). Framing the framework: Discourses in Australia's national values education policy. Educational Research for Policy and Practice, 8, 35-57.

LePage, P., Akar, H., Temli, Y., Şen, D., Hasser, N., \& Ivins, I. (2011). Comparing teachers' views on morality and moral education, a comparative study in Turkey and the United States. Teaching and Teacher Education, 27, 366-375.

Ling, L., Burman, E. \& Cooper, M. (1998). The Australian study. In J. Stephenson, L. Ling, E. Burman \& M. Cooper (Eds.), Values in education (pp. 35-60). London: Routledge.

Lovat, T. (2011). Values education and holistic learning: Updated research perspectives. International Journal of Educational Research, 50, 148-152.

Lovat, T., Dally, K., \& Toomey, R. (2011). The impact of values education on school ambience and academic diligence. International Journal of Educational Research, 50, 166-170.

Ministry of National Education. (MoNE). (1973). Milli Eğitim Temel Kanunu [Basic Law of National Education]. No. 1739. Ankara: MoNE.

Narvaez, D. (2006). Integrative ethical education. In M Killen \& J. G. Smetana (Eds.), Handbook of moral development (pp. 703-732). New Jersey: Lawrence Erlbaum Associates.

Nucci, L. P. (2006). Education for moral development. In M. Killen \& J. G. Smetana (Eds.), Handbook of moral development (pp. 657-681). New Jersey: Lawrence Erlbaum Associates.

Oğuz, E. (2012). Öğretmen adaylarının değerler ve değerler eğitimine ilis, kin görüs, leri [Views of pre-service teachers on values and value education]. Kuram ve Uygulamada Eğitim Bilimleri, 12, 1309-1325.

Ohnstad, F. O. (2005). Using focus-groups with teachers - a way to develop teachers' ethical consciousness? How do teachers utter their ethical statements and reflections by participating in focus groups? Paper presented at the $33^{\text {rd }}$ Congress of Nordic Educational Research Association in Norway at the Faculty of Education, University of Oslo, March 10-12, 2005.

Orlenius, K. (2001). Värdegrunden-finns den? [The foundation of values-does it exist?]. Stockholm: Runa Förlag.

Power, F. C., Higgins, A. \& Kohlberg, L. (1989). Lawrence Kohlberg's approach to moral education. New York: Columbia University Press.

Powney, J., Cullen, M-A., Schlapp, U., Johnstone, M. \& Munn, P. (1995). Understanding values education in the primary school. York: Reports Express.

Sanger, M. \& Osguthorpe, R. (2005). Making sense of approaches to moral education. Journal of Moral Education, 34, 57-71.

Sanger, M. N., \& Osguthorpe, R. D. (2013). Modeling as moral education: Documenting, analyzing, and addressing a central belief of preservice teachers. Teaching and Teacher Education, 29, 167-176.

Shapira-Lishchinsky, O. (2009). Towards professionalism: Ethical perspectives of Israeli teachers. European Journal of Teacher Education, 32, 473-487.

Shapira-Lishchinsky, O. (2011). Teachers' critical incidents: Ethical dilemmas in teaching practice. Teaching and Teacher Education, 27, 648-656.

Şişman, M. (2012). Preface. Kuram ve Uygulamada Ĕ̌itim Bilimleri.[Educational Sciences: Theory and Pactice].12 (2).

Skolverket [The National Agency for Education] (2011). Läroplan för grundskolan, förskoleklassen och fritidshemmet 2011 [The national curriculum policy document for the primary school, preschool classes and after-school centres]. Stockholm: Liber Distribution.

Sockett, H., \& LePage, P. (2002). The missing language of the classroom. Teaching and Teacher Education, 18, 159-171.

Solomon, D., Watson, M., Battistich, V. A. (2001). Teaching and schooling effects on moral/prosocial development. In V. Richardson (Ed.), Handbook of research on teaching (4 ${ }^{\text {th }}$ ed., pp. 566-603). Washington, D C: American Educational Research Association. 
Svingby, G. (1994). Sweden. In M. Taylor (Ed.), Values education in Europe: A comparative overview of a survey of 26 countries in 1993 (pp. 195-198). Dundee: Scottish Consultative Council on the Curriculum.

Taylor, M. (1994). Overview of values education in 26 European countries. In M, Taylor (Ed.), Values education in Europe: A comparative overview of a survey of 26 countries in 1993 (pp. 1-66). Dundee: Scottish Consultative Council on the Curriculum.

Taylor, M. (2006). The development of values through the school curriculum. In R. H. M. Cheng, J. C. K. Lee \& L. N. K. Lo (Eds.), Values education for citizens in the new century (pp. 107-131). Sha Tin: The Chinese University Press.

Thayer-Bacon, B. J. (2001). An examination and redescription of epistemology. In J. K. Kincheloe \& D. Weil (Eds.), Standards and schooling in the United States: An encyclopedia (Vol. 1, pp. 397-418). Santa Barbara, CA: ABC-CLIO.

Thornberg, R. (2008a). The lack of professional knowledge in values education. Teaching and Teacher Education, 24, 1791-1798.

Thornberg, R. (2008b). Values education as the daily fostering of school rules. Research in Education, 80, 5262.

Tirri, K. (2011). Holistic school pedagogy and values: Finnish teachers' and students' perspectives. International Journal of Educational Research, 50, 159-165.

Yıldırım, K. (2009). Values education experiences of Turkish class teachers: A phenomenological approach. Egitim Arastirmalari-Eurasian Journal of Educational Research, 35, 165-184. 